\title{
Regulation of Sodium Transport in the Proximal Tubule by Endothelin
}

\author{
Ye Zhang ${ }^{a, b} \cdot$ Pedro A. Jose $\cdot$ Chunyu Zeng ${ }^{a, b}$
}

aDepartment of Cardiology, Daping Hospital, The Third Military Medical University, and ${ }^{\text {bChongqing }}$ Institute of Cardiology, Chongqing, P.R. China; 'Center for Molecular Physiology Research, Children's National Medical Center and Department of Pediatrics, George Washington University School of Medicine and Public Health, Washington, D.C., USA

\begin{abstract}
Human essential hypertension and rodent genetic hypertension are associated with increased sodium transport in the renal proximal tubule and medullary thick ascending limb of Henle. The proximal tubule, which secretes endothelin (ET), expresses the $E T_{B}$ receptor. Low (nM) concentrations of $\mathrm{ET}$, via the $\mathrm{ET}_{\mathrm{B}}$ receptor, inhibit sodium and water transport and ATP-driven drug secretion in the proximal tubule. In contrast, very low (рм) and high nM concentrations of ET increase renal proximal sodium transport, but the receptor involved remains to be determined. The natriuretic effect of $\mathrm{ET}_{\mathrm{B}}$ receptor stimulation is impaired in spontaneously hypertensive rats, due in part to a defective interaction with $\mathrm{D}_{3}$ dopamine and angiotensin II type 1 receptors. Impaired $\mathrm{ET}_{\mathrm{B}}$ receptor function in the renal proximal tubule may be important in the pathogenesis of genetic hypertension.
\end{abstract}

Copyright $\odot 2011$ S. Karger AG, Basel

The kidney is important in the long-term regulation of blood pressure and is the major organ involved in the regulation of body sodium homeostasis [1-3]. The proximal tubule and medullary thick ascending limb of Henle are pre-eminent in the overall regulation of sodium balance in essential hypertension [4]. Indeed, several studies have shown that human essential hypertension and rodent genetic hypertension are associated with increased sodium transport in the renal proximal tubule and medullary thick ascending limb of Henle [4].

Endothelin (ET) was initially identified as an endothelial cell-derived peptide, with the greatest vasoconstrictor potency of any known endogenous compound [5]. ETs are a family of isopeptides (ET-1, ET-2, and ET-3), with at least 
two receptors subtypes $\left(\mathrm{ET}_{\mathrm{A}}\right.$ and $\left.\mathrm{ET}_{\mathrm{B}}\right)$. Renal tissue expresses both $\mathrm{ET}$ receptor subtypes [6], and ET is secreted by renal tubules, including the renal proximal tubule $[7,8]$, where it can regulate sodium transport in an autocrine/paracrine manner [9]. In the renal proximal tubules, ET-1 (the major ET expressed in the renal proximal tubule) inhibits ion transport principally through the $\mathrm{ET}_{\mathrm{B}}$ receptor [10], an effect opposite that of the $\mathrm{ET}_{\mathrm{A}}$ receptor. This review focuses on the regulation of ET on sodium transport in the renal proximal tubule and its role in the pathogenesis of essential hypertension.

\section{Endothelin and Its Metabolism}

In 1985, Hickey et al. [11] described the existence of a trypsin-sensitive endothelium-derived constricting factor in cultured bovine endothelial cells, which they named as ET. Subsequently, more ET family members were found. These members include ET-1, ET-2, ET-3, and ET-4 (analogue of human ET-2 in rat and mouse, also named as a vasoactive intestinal contractor), as well as three isoforms of 31-amino-acid ETs (ET-1 ${ }^{1-31}$, ET-2 ${ }^{1-31}$, and ET-3 ${ }^{1-31}$ ) [12]. Owing to the similarity of actions between ET- $1^{1-31}$ and ET-1 in vivo, it is possible that some of the effects of $\mathrm{ET}^{1-31}$ result from their partial bioconversion into ETs [13]. Among these isoforms, ET-1 is the principal isoform and is the most potent and long-lasting constrictor of human vessels known to date [5].

ET-1 is produced in many cell types in the renal and cardiovascular systems, such as endothelial cells, smooth muscle cells, cardiomyocytes, leucocytes, macrophages, and renal tubular and mesangial cells [14, 15]. Bioactive ETs are the product of post-translational processing of the parent preproET peptide. The transcription and translation of preproET result in the formation of a 203-amino-acid peptide which is subsequently cleaved by a furin convertase to the 38-amino-acid peptide big $\mathrm{ET}^{1-38}$. Big ET is processed further into $\mathrm{ET}^{1-31}$ by different isoforms of ET-converting enzymes (ECEs), a group of proteases that belong to the metalloprotease family [16], including ECE-1a, ECE-1b, ECE-1c, and ECE-1d, derived from a single gene by the action of alternative promoters.

ET synthesis is regulated by many factors. It is enhanced in response to lowshear stress, turbulent blood flow, hypoxia, cytokines, angiotensin II, epinephrine, and low-density lipoproteins [17]. In contrast, high-shear stress, nitric oxide, vasodilating prostaglandins, and natriuretic peptides suppress ET production [18]. ET synthesis is regulated by sodium diet; a high-sodium diet, independent of blood pressure status, increases renal synthesis of ET [19]. Distal nephron segments synthesize ET-1 to a greater extent than the proximal tubule [8].

Synthesized ET-1 is released in two ways. One way is via a constitutive pathway, producing intense constriction of the underlying smooth muscle, which contributes to the maintenance of endogenous vascular tone. The other way is via release from endothelial cell-specific storage granules (Weibel-Palade 
bodies) in response to external physiological stimuli, producing further vasoconstriction [20]. Although plasma ET-1 is present in the highest concentration in blood/plasma, compared with ET-2 and ET-3, ET-1 concentrations are still lower in plasma than in endothelial and other cells. It is accepted that ET-1 functions as a locally released, rather than a circulating, hormone.

\section{Endothelin Receptors}

\section{Endothelin Receptor Classification}

$\mathrm{ET}$ receptors are classified as $\mathrm{ET}_{\mathrm{A}}$ and $\mathrm{ET}_{\mathrm{B}}$ by the International Union of Pharmacology Committee on Receptor Nomenclature and Drug Classification [21]. Both $\mathrm{ET}_{\mathrm{A}}$ and $\mathrm{ET}_{\mathrm{B}}$ receptors belong to the 7-transmembrane domain or $\mathrm{G}$ protein-coupled rhodopsin-type receptor superfamily. Pharmacologically heterogeneous responses seem to be related to the existence of alternatively spliced variants of $\mathrm{ET}_{\mathrm{A}}$ and $\mathrm{ET}_{\mathrm{B}}$ receptors. A third receptor, named $\mathrm{ET}_{\mathrm{C}}$, which is specific for ET-3 binding, was cloned from dermal melanophores from the amphibian Xenopus laevis, but a mammalian homologue has yet to be identified [21] (see below).

The three ET receptors have different affinities to the three isoforms of ET (ET-1, ET-2, and ET-3). ET receptors can bind all ET isoforms, but the $\mathrm{ET}_{\mathrm{A}}$ receptor has a much higher affinity for ET-1, the most abundant ET in human plasma, than for ET-3, while the $\mathrm{ET}_{\mathrm{C}}$ receptor has a higher affinity for ET-3 than ET-1. In contrast, the $\mathrm{ET}_{\mathrm{B}}$ receptor binds to all three $\mathrm{ET}$ isoforms with equal affinity.

\section{Localization of Endothelin Receptors}

In all species studied, including humans, ET-binding is greater in the renal inner medulla than in the inner cortex $[8,22,23]$.

In the rat, there is faint immunostaining of the $\mathrm{ET}_{\mathrm{A}}$ receptor in the proximal convoluted and straight tubules, restricted to the basal side, and intense staining in the distal tubule collecting duct $[24,25]$. The $\mathrm{ET}_{\mathrm{A}}$ receptor is also expressed in mesangial cells, pericytes of descending vasa recta, and vascular smooth muscle cells of veins and arteries, specifically the interlobar, arcuate, and interlobular arteries, as well as efferent and afferent arterioles [25]. The $\mathrm{ET}_{\mathrm{B}}$ receptor is the major ET receptor in the kidney; 70-80\% of ET receptors in the kidney are $\mathrm{ET}_{\mathrm{B}}$ receptors $[6,8]$, which in the rat are expressed in the proximal tubule, inner medullary collecting duct, glomerular capillaries, vasa recta endothelial cells, and vascular smooth muscle cells of interlobular, efferent, and afferent arteries [25-28].

In the mouse, the $\mathrm{ET}_{\mathrm{A}}$ receptor has been shown to be expressed in some proximal tubules and vessels, but not in glomeruli. In agreement with the rat studies, the $\mathrm{ET}_{\mathrm{B}}$ receptor is expressed in the proximal tubule and collecting duct [29]. 
Faint staining of $\mathrm{ET}_{\mathrm{A}}$ and $\mathrm{ET}_{\mathrm{B}}$ receptors has also been reported in human glomeruli, and proximal and distal tubules. In agreement with the rat studies, the distal nephron expresses more ET receptors than the proximal nephron $[30,31]$.

\section{Signal Transduction of Endothelin Receptors in the Renal Proximal Tubules}

Both $\mathrm{ET}_{\mathrm{A}}$ and $\mathrm{ET}_{\mathrm{B}}$ receptors are linked to $\mathrm{Gq} / 11, \mathrm{Ga}_{\mathrm{S}}$, and $\mathrm{Ga}_{\mathrm{i} / \mathrm{O}}[32,33]$. In some cells (e.g. Chinese hamster ovary cells), the $\mathrm{ET}_{\mathrm{A}}$ receptor is linked to $\mathrm{Ga}_{\mathrm{S}}$ while the $\mathrm{ET}_{\mathrm{B}}$ receptor is linked to $\mathrm{Ga}_{\mathrm{i}}$ [34]. However, in hepatocytes, the $\mathrm{ET}_{\mathrm{B}}$ receptor is also linked to $\mathrm{Ga}_{S}[35]$. The $\mathrm{ET}_{\mathrm{B}}$, but the $\mathrm{ET}_{\mathrm{A}}$, receptor also activates $\mathrm{Ga}_{13}[36]$.

In rat renal brush border membranes, the ET-mediated increase in phospholipase $\mathrm{C}$ activity and protein kinase $\mathrm{C}$ translocation to the brush border membrane are mediated by the $\mathrm{ET}_{\mathrm{B}}$ but not the $\mathrm{ET}_{\mathrm{A}}$, receptor. In contrast, the $\mathrm{ET}_{\mathrm{C}}$ receptor is involved in ET-mediated signaling in basolateral membranes [37]. Both the $\mathrm{ET}_{\mathrm{A}}$ and $\mathrm{ET}_{\mathrm{B}}$ receptors belong to the class A receptors of the $\mathrm{G}$ proteincoupled receptor family because they bind to $\beta$-arrestin 1 with a higher affinity than $\beta$-arrestin 2 , and do not bind to visual arrestin $[38,39]$.

\section{Effect of Endothelin on Renal Proximal Tubule Transport}

\section{In vivo Studies}

Low-dose infusion of ET in anesthetized rats has been reported to decrease sodium transport in proximal and distal nephron segments, assessed by lithium clearance, which is associated with an increase in renal blood flow, but not glomerular filtration rate [40]. At a dose that does not alter renal plasma flow, ET also decreases proximal but not distal tubule sodium reabsorption, also assessed by lithium clearance [8, 41, 42]. This shows that ET infusion causes natriuresis without altering glomerular filtration rate or renal blood flow, and suggests a direct inhibitory effect of ET-1 on $\mathrm{Na}^{+}$transport along the nephron. However, ET-mediated natriuresis has not been consistently observed $[43,44]$. One group reported that the natriuretic effect of exogenous ET-1 is due solely to an increase in blood pressure since renal decapsulation or maintaining renal perfusion pressure at baseline values (ET agonists often increase arterial pressure) with an aortic clamp prevents ET-1-induced natriuresis [43]. The possible explanation for the inconsistent findings on ET agonist-induced natriuresis may be due, at least partly, to differential activation of $\mathrm{ET}_{\mathrm{A}}$ and $\mathrm{ET}_{\mathrm{B}}$ receptors. For example, when the $\mathrm{ET}_{\mathrm{A}}$ receptor, but not the $\mathrm{ET}_{\mathrm{B}}$ receptor, is blocked, a natriuretic effect of ET-1 is detected [45]. One study showed that low doses of ET causes a natriuresis by decreasing renal proximal tubular reabsorption that is not due to $\mathrm{ET}_{\mathrm{B}}$ receptors [46]. 
In contrast to the studies on sodium excretion, there is unanimous agreement that systemically administered ET increases urinary water excretion. Even when given at doses that markedly decreased renal blood flow, the renal arterial infusion of ET-1 increased urine volume and free water clearance [47]. This effect may be mediated by the $\mathrm{ET}_{\mathrm{B}}$ receptor because the infusion of $\mathrm{ET}_{\mathrm{B}}$-specific agonists (IRL1620 or sarafotoxin 6c) increases urine flow $[10,46]$.

The $\mathrm{ET}_{\mathrm{B}}$ receptor also works as a clearance receptor. The $\mathrm{ET}_{\mathrm{B}}$ receptor in endothelial cells removes ET-1 from the circulation $[48,49]$. Blockade of the $\mathrm{ET}_{\mathrm{B}}$ receptor increases circulating immunoreactive ETs (ET-1 and ET-3), and mice with genetic ablation of the $\mathrm{ET}_{\mathrm{B}}$ receptor in endothelial cells have elevated plasma concentrations of ET-1 [48, 49].

\section{In vitro Studies}

ET has diverse effects throughout the nephron. In the rat proximal tubule, ET has a biphasic effect on ion and fluid transport [50]. Low concentrations ( $\mathrm{pm}$ ) increase, whereas a high concentration (low nM) of ET-1 decreases fluid transport through protein kinase C-, cyclooxygenase- and lipoxygenase-dependent mechanisms [42, 50]. However, higher concentrations (high nм) of ET also increase renal proximal tubule transport [7]. In agreement with the data on sodium transport, low nM concentrations of $\mathrm{ET}$, via the $\mathrm{ET}_{\mathrm{B}}$ receptor, have also been shown to inhibit the secretion of fluorescent substrates in renal proximal tubules of the killifish [51].

ET-1 inhibits fluid and bicarbonate absorption in the isolated-perfused rat proximal straight tubule [52] and fluid transport in the midproximal convoluted tubule measured by the split-drop micropuncture method [53]. A preliminary report also indicates that ET decreases sodium-phosphate cotransport in rat renal brush border membranes [53, 54]. Garvin and Sanders [52] showed that the ability of ET to inhibit fluid and bicarbonate transport in the rat proximal straight tubule is mediated by a reduction in $\mathrm{Na}^{+}-\mathrm{K}^{+}$ATPase activity. These effects are probably mediated by the $\mathrm{ET}_{\mathrm{B}}$ receptor because stimulation of the $\mathrm{ET}_{\mathrm{B}}$ receptor also inhibits $\mathrm{Na}^{+}-\mathrm{K}^{+}$ATPase activity in immortalized rat $\mathrm{S} 1$ renal proximal tubule cells [55], similar to that observed in proximal tubules, with a reduction of about $20-40 \%[52,53]$. The inhibitory effect of ET, via the $\mathrm{ET}_{\mathrm{B}}$ receptor, on $\mathrm{Na}^{+}-\mathrm{K}^{+}$ATPase activity in human and rat renal proximal tubule cells is mediated by an increase in intracellular calcium via phosphatidyl inositol-3 kinase [55]. However, in suspensions of rabbit proximal tubule cells, ET was not found to reduce oxygen consumption, which is used as an index of $\mathrm{Na}^{+}-\mathrm{K}^{+}$ATPase activity [56]. It remains to be determined whether or not the differential effect of ET on $\mathrm{Na}^{+}-\mathrm{K}^{+}$ATPase activity between rats and rabbits is related to species differences.

The effect of ET on NHE3 activity in renal proximal tubule cells is still controversial. Short-term $(<1 \mathrm{~h})$ incubation of rat renal cortical slices with ET increases NHE3 activity that is mediated by protein kinase $\mathrm{C}$ and inhibition 
of cAMP production [57]. Short-term $(<1 \mathrm{~h})$ stimulation with ET of opossum kidney cells which express $\mathrm{ET}_{\mathrm{B}}$ but not $\mathrm{ET}_{\mathrm{A}}$ receptors, also increases NHE3 that is mediated equally by $\mathrm{Ca}^{2+}$-dependent and tyrosine kinase-dependent pathways $[58,59]$. However, long-term $(\geq 6 \mathrm{~h})$ stimulation of the $\mathrm{ET}_{\mathrm{B}}$ receptor in the same opossum kidney cells leads to inhibition of NHE3 activity and expression [60]. One may conclude from these studies that in the renal proximal tubule, ET, via the $\mathrm{ET}_{\mathrm{B}}$ receptor, inhibits sodium transport by decreasing $\mathrm{Na}^{+}-\mathrm{K}^{+}$ATPase activity. In contrast, $\mathrm{ET}$, via the $\mathrm{ET}_{\mathrm{B}}$ receptor, acutely stimulates, but chronically inhibits NHE3 activity. However, the end-result of $\mathrm{ET}_{\mathrm{B}}$ receptor stimulation should still be a decrease in renal proximal tubule transport because of the inhibition of $\mathrm{Na}^{+}-\mathrm{K}^{+}$ATPase activity.

\section{Interaction with Other G Protein-Coupled Receptors}

\section{Interaction between Endothelin $A$ and Endothelin B Receptors}

$\mathrm{ET}_{\mathrm{A}}$ and $\mathrm{ET}_{\mathrm{B}}$ receptors may exist as constitutive homodimers [61]. They may also exist as constitutive heterodimers [62]; therefore, there may be a 'cross-talk' between these two ET receptors. The $\mathrm{ET}_{\mathrm{B}}$ receptor may be essential in regulating the development or expression of the $\mathrm{ET}_{\mathrm{A}}$ receptor because $\mathrm{ET}_{\mathrm{A}}$ receptor expression is decreased in central or peripheral tissues of $\mathrm{ET}_{\mathrm{B}}$ receptor-deficient mice [63]. $\mathrm{ET}_{\mathrm{A}}$ and $\mathrm{ET}_{\mathrm{B}}$ receptor heterodimers may be responsible for a sustained $\mathrm{Ca}^{2+}$ signaling by delaying their internalization [64]. Both the $\mathrm{ET}_{\mathrm{A}}$ and $\mathrm{ET}_{\mathrm{B}}$ receptors are required for the full diuretic and natriuretic actions of ET associated with the intramedullary hyperosmotic saline infusion [65]. An increased ratio of $\mathrm{ET}_{\mathrm{A}}$ and $\mathrm{ET}_{\mathrm{B}}$ receptor activity is important in the development and progression of DOCA-salt-induced hypertension and organ damage [66]. Indeed, blockade of $\mathrm{ET}_{\mathrm{B}}$ receptors in this model of hypertension increases the severity of vascular and renal proximal tubular damage [66].

\section{Interaction with the $D_{3}$ Dopamine Receptor}

Dopamine, an endogenous catecholamine, is an important regulator of sodium balance and blood pressure via renal and nonrenal mechanisms, including the regulation of appetite centers in the brain, secretion/release of hormones, and humoral agents, as well as interaction with hormones that regulate renal ion transport. Dopamine receptors are divided into $\mathrm{D}_{1}$ - and $\mathrm{D}_{2}$-like subtypes based on their interaction with the effector enzyme adenylyl cyclase. Among $\mathrm{D}_{2}$-like receptor subtypes, the $\mathrm{D}_{3}$ receptor, along with the $\mathrm{D}_{4}$ receptor, has the highest affinity for dopamine. Stimulation of the $\mathrm{D}_{3}$ receptor increases sodium and water excretion in normotensive rats $[67,68]$. The natriuresis caused by $\mathrm{D}_{3}$ receptor stimulation is due, in part, to inhibition of $\mathrm{Na}^{+}-\mathrm{K}^{+}$ATPase activity via a cooperative interaction with $\mathrm{ET}_{\mathrm{B}}$ receptors [28]. The $\mathrm{D}_{3}$ and $\mathrm{ET}_{\mathrm{B}}$ receptors colocalize and physically interact in rat renal proximal tubules and increase each other's expression (fig. 1). 


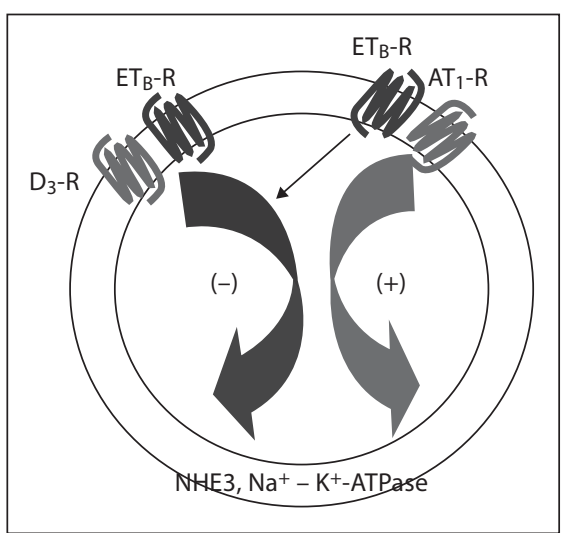

Fig. 1. Interactions among $E T_{B}\left(E T_{B}-R\right), D_{3}$ dopamine $\left(D_{3}-R\right)$, and $A T_{1}\left(A T_{1}-R\right)$ receptors in the regulation of sodium transport in the renal proximal tubule. Stimulation of the $A T_{1}-R$ increases the activity of sodium transporters, sodium exchangers, and the sodium pump (e.g. $\mathrm{NaHCO}_{3}$ cotransporter, $\mathrm{Na}^{+} \mathrm{H}^{+}$exchanger, and $\mathrm{Na}^{+}-\mathrm{K}^{+}$-ATPase), while their activity is decreased by the stimulation of $E T_{B}-R$ and dopamine receptors (e.g. $D_{1}-R$ and $D_{3}-R$ ). $E T_{B}-R$, $D_{3}-R$, and $A T_{1}-R$ physically interact with each other. Stimulation of the $E T_{B}-R$ increases $D_{3}-R$ expression and function, but the opposite effect occurs with $A T_{1}-R$ expression and function. The $D_{3}-R$ also negatively regulates $A T_{1}-R$ expression. In contrast, stimulation of the $A T_{1}-R$ increases $E T_{B}-R$ expression in the long term, and $E T_{B}-R$ cell surface expression in the short term. Thus, the $E T_{B}-R$ synergistically interacts with the $D_{3}-R$ to counterbalance the stimulatory effect of the $\mathrm{AT}_{1}-\mathrm{R}$ on sodium transport in the renal proximal tubule.

In immortalized renal proximal tubule cells, $\mathrm{D}_{3}$ receptor stimulation increases $\mathrm{ET}_{\mathrm{B}}$ receptor expression by a calcium-mediated process which is absent in renal proximal tubule cells from spontaneously hypertensive rats $[69,70]$.

\section{Interaction with the $A T_{1}$ Receptor}

In the basal state of normal sodium intake and especially during sodium deficit, angiotensin II, via the $\mathrm{AT}_{1}$ receptor, is pre-eminent in renal sodium conservation. The $\mathrm{AT}_{1}$ and $\mathrm{ET}_{\mathrm{B}}$ receptors physically interact and regulate each other's expression (fig. 1). Long-term activation of the $\mathrm{AT}_{1}$ receptor increases $\mathrm{ET}_{\mathrm{B}}$ receptor expression, whereas short-term activation increases cell surface $\mathrm{ET}_{\mathrm{B}}$ receptor expression in rat renal proximal tubule cells, effects that are not observed in renal proximal tubule cells from spontaneously hypertensive rats $[71,72]$.

\section{Endothelin and Hypertension}

Increased ET-1 plasma levels, relative to normotensive subjects, regardless of renal function, have been reported in hypertensive patients in some studies 
[73-75]. Most studies, however, have found no differences in circulating ET levels between hypertensive and normotensive subjects [76]. However, the $\mathrm{ET}_{\mathrm{B}}$ receptor may be involved in the pathogenesis of hypertension. A highsodium diet or deoxycorticosterone-salt treatment increases the blood pressure of $\mathrm{ET}_{\mathrm{B}}$ receptor-deficient rats. The increased renal sodium transport in these rats probably occurs at a distal tubular level because the increased blood pressure caused by an increased-sodium diet is normalized by blockade of the epithelial sodium channel with amiloride [77]. $\mathrm{ET}_{\mathrm{B}}$ receptor blockade produces hypertension that is exaggerated by salt intake or deoxycorticosterone $[78,79]$. Systemic $\mathrm{ET}_{\mathrm{B}}$ receptor blockade also produces hypertension in mice that is maintained by the $\mathrm{ET}_{\mathrm{A}}$ receptor [80]. These findings strongly suggest that the $\mathrm{ET}_{\mathrm{B}}$ receptor, by itself or in conjunction with the $\mathrm{ET}_{\mathrm{A}}$ receptor, can regulate blood pressure and decreased expression or activity of $\mathrm{ET}_{\mathrm{B}}$ receptors increases blood pressure. However, these studies have not determined the involvement of the $\mathrm{ET}_{\mathrm{B}}$ receptor expressed in the proximal tubule. As indicated above, the natriuretic effect of $\mathrm{ET}_{\mathrm{B}}$ receptor agonists is impaired in spontaneously hypertensive rats. Although $\mathrm{ET}_{\mathrm{B}}$ receptor expression is not different in renal proximal tubules between normotensive and spontaneously hypertensive rats, angiotensin $\mathrm{II}$ increases total $\mathrm{ET}_{\mathrm{B}}$ receptor expression or plasma membrane expression in cells from normotensive, but not hypertensive, rats [71]. The physical interaction between $\mathrm{ET}_{\mathrm{B}}$ and $\mathrm{AT}_{1}$ receptors is also impaired in renal proximal tubule cells from spontaneously hypertensive rats [72]. The blunted natriuretic effect of dopamine in spontaneously hypertensive rats may also be due to an impaired physical interaction between $\mathrm{D}_{3}$ and $\mathrm{ET}_{\mathrm{B}}$ receptors in the proximal tubule [28], resulting in the impaired inhibition of $\mathrm{Na}^{+}-\mathrm{K}^{+}$ ATPase activity [70].

\section{Conclusion}

The renal proximal tubule in all studied species expresses the $\mathrm{ET}_{\mathrm{B}}$ receptor. $\mathrm{ET}$ has a U-shaped effect on ion and fluid absorption in the renal proximal tubule. The natriuretic effect of $\mathrm{ET}_{\mathrm{B}}$ receptor agonists and low nM concentrations of ET is, in part, due to inhibition of sodium and water transport in the proximal tubule. This is due mainly to inhibition of $\mathrm{Na}^{+}-\mathrm{K}^{+}$ATPase activity and NHE3 activity, the latter occurring only in the long term, as acute stimulation of $\mathrm{ET}_{\mathrm{B}}$ receptors increases NHE3 activity. The inhibition of $\mathrm{Na}^{+}-\mathrm{K}^{+}$ATPase activity in renal proximal tubules by stimulation of the $\mathrm{ET}_{\mathrm{B}}$ receptor that results in natriuresis is probably abetted by increased positive interaction with the $\mathrm{D}_{3}$ receptor and negative interaction with the $\mathrm{AT}_{1}$ receptor. The impaired natriuretic effect of $\mathrm{ET}_{\mathrm{B}}$ receptor stimulation in spontaneously hypertensive rats may be caused by impaired $\mathrm{ET}_{\mathrm{B}}$ receptor function that may be related to impaired interaction with $\mathrm{D}_{3}$ and $\mathrm{AT}_{1}$ receptors. 


\section{Acknowledgements}

These studies were supported in part by grants from the National Institutes of Health, USA (HL023081, HL074940, DK039308, HL068686, HL092196), the National Natural Science Foundation of China (30470728, 30672199, 81070259), Natural Science Foundation Project of CQ CSTC (2009BA5044), and the grants for Distinguished Young Scholars of China from the National Natural Science Foundation of China (30925018).

\section{References}

$>1$ Crowley SD, Coffman TM: In hypertension, the kidney rules. Curr Hypertens Rep 2007;9:148-153.

2 Hall JE: The kidney, hypertension, and obesity. Hypertension 2003;41:625-633.

\3 Asico L, Zhang X, Jiang J, Cabrera D, Escano CS, Sibley DR, Wang X, Yang Y, Mannon R, Jones JE, Armando I, Jose PA: Lack of renal dopamine $\mathrm{D}_{5}$ receptors promotes hypertension. J Am Soc Nephrol 2011;22:82-89.

$\checkmark 4$ Doris PA: Renal proximal tubule sodium transport and genetic mechanisms of essential hypertension. J Hypertens 2000;18:509519.

5 Yanagisawa M, Kurihara H, Kimura S, Tomobe Y, Kobayashi M, Mitsui Y, Yazaki Y, Goto K, Masaki T: A novel potent vasoconstrictor peptide produced by vascular endothelial cells. Nature 1988;332:411-415.

6 Schneider MP, Boesen EI, Pollock DM: Contrasting actions of endothelin $\mathrm{ET}_{\mathrm{A}}$ and $\mathrm{ET}_{\mathrm{B}}$ receptors in cardiovascular disease. Annu Rev Pharmacol Toxicol 2007;47:731759.

7 Romano G, Giagu P, Favret G, Bartoli E: Effect of endothelin 1 on proximal reabsorption and tubuloglomerular feedback. Kidney Blood Press Res 2000;23:360-365.

$>8$ Kohan DE, Rossi NF, Inscho EW, Pollock DM: Regulation of blood pressure and salt homeostasis by endothelin. Physiol Rev 2011;91:1-77.

$>9$ Licht C, Laghmani K, Yanagisawa M, Preisig PA, Alpern RJ: An autocrine role for endothelin-1 in the regulation of proximal tubule NHE3. Kidney Int 2004;65:13201326.
10 Matsuo G, Matsumura Y, Tadano K, Hashimoto T, Morimoto S: Effects of sarafotoxin S6c on renal haemodynamics and urine formation in anaesthetized dogs. Clin Exp Pharmacol Physiol 1997;24:487-491.

11 Hickey KA, Rubanyi G, Paul RJ, Highsmith RF: Characterization of a coronary vasoconstrictor produced by cultured endothelial cells. Am J Physiol 1985;248:C550-C556.

12 Kishi F, Minami K, Okishima N, Murakami M, Mori S, Yano M, Niwa Y, Nakaya Y, Kido $\mathrm{H}$ : Novel 31-amino-acid-length endothelins cause constriction of vascular smooth muscle. Biochem Biophys Res Commun 1998;248:387-390.

13 Fecteau MH, Honoré JC, Plante M, Labonté J, Rae GA, D’Orléans-Juste P: Endothelin-1 (1-31) is an intermediate in the production of endothelin-1 after big endothelin-1 administration in vivo. Hypertension 2005;46:87-92.

14 Brunner F, Brás-Silva C, Cerdeira AS, LeiteMoreira AF: Cardiovascular endothelins: essential regulators of cardiovascular homeostasis. Pharmacol Ther 2006;111:508-531.

15 Granger JP, Abram S, Stec D, Chandler D, LaMarca B: Endothelin, the kidney, and hypertension. Curr Hypertens Rep 2006;8:298-303.

16 Turner AJ, Barnes K, Schweizer A, Valdenaire O: Isoforms of endothelinconverting enzyme: why and where? Trends Pharmacol Sci 1998;19:483-486.

17 Martínez-Miguel P, Raoch V, Zaragoza C, Valdivielso JM, Rodríguez-Puyol M, Rodríguez-Puyol D, López-Ongil S: Endothelin-converting enzyme-1 increases in atherosclerotic mice: potential role of oxidized low density lipoproteins. J Lipid Res 2009;50:364-375. 
18 Papachristou E, Papadimitropoulos A, Kotsantis P, Goumenos DS, Katsoris PG, Vlachojannis JG: Interaction of endothelin-1 and nitric oxide pathways in human tubular epithelial cells under the influence of cyclosporine A. Ren Fail 2010;32:727-732.

19 Pollock DM, Pollock JS: Evidence for endothelin involvement in the response to high salt. Am J Physiol Renal Physiol 2001;281:F144-F150.

20 Russell FD, Skepper JN, Davenport AP: Human endothelial cell storage granules: a novel intracellular site for isoforms of the endothelin-converting enzyme. Circ Res 1998;83:314-321.

21 Davenport AP: International Union of Pharmacology. XXIX. Update on endothelin receptor nomenclature. Pharmacol Rev 2002;54:219-226.

22 Lattmann T, Shaw S, Münter K, Vetter W, Barton M: Anatomically distinct activation of endothelin-3 and the L-arginine/nitric oxide pathway in the kidney with advanced aging. Biochem Biophys Res Commun 2005;327:234-241.

23 Goettsch W, Lattmann T, Amann K, Szibor M, Morawietz H, Münter K, Müller SP, Shaw S, Barton M: Increased expression of endothelin-1 and inducible nitric oxide synthase isoform II in aging arteries in vivo: implications for atherosclerosis. Biochem Biophys Res Commun 2001;280:908-913.

-24 Yamamoto T, Suzuki H, Kubo Y, Matsumoto A, Uemura H: Endothelin A receptor-like immunoreactivity on the basal infoldings of rat renal tubules and collecting ducts. Arch Histol Cytol 2008;71:77-87.

25 Wendel M, Knels L, Kummer W, Koch T: Distribution of endothelin receptor subtypes $\mathrm{ET}_{\mathrm{A}}$ and $\mathrm{ET}_{\mathrm{B}}$ in the rat kidney. J Histochem Cytochem 2006;54:1193-1203.

26 Francis BN, Abassi Z, Heyman S, Winaver J, Hoffman A: Differential regulation of $\mathrm{ET}_{\mathrm{A}}$ and $\mathrm{ET}_{\mathrm{B}}$ in the renal tissue of rats with compensated and decompensated heart failure. J Cardiovasc Pharmacol 2004;44(Suppl 1):S362-S365.

27 Schiffrin EL: Vascular endothelin in hypertension. Vascul Pharmacol 2005;43:19-29.
28 Zeng C, Asico LD, Yu C, Villar VA, Shi W, Luo Y, Wang Z, He D, Liu Y, Huang L, Yang C, Wang X, Hopfer U, Eisner GM, Jose PA: Renal $\mathrm{D}_{3}$ dopamine receptor stimulation induces natriuresis by endothelin $\mathrm{B}$ receptor interactions. Kidney Int 2008;74:750-759.

29 Lee S, Ahn D: Expression of endothelin-1 and its receptors in cisplatin-induced acute renal failure in mice. Korean J Physiol Pharmacol 2008;12:149-153.

30 Frank K, Zeier M, Gross ML, Waldherr R, Ritz E, Amann K: Comprehensive immunohistological analysis of the endothelin system in human kidney grafts. Nephrol Dial Transplant 2006;21:1365-1372.

31 Karet FE: Endothelin peptides and receptors in human kidney. Clin Sci (Lond) 1996;91:267-273.

32 Takigawa M, Sakurai T, Kasuya Y, Abe Y, Masaki T, Goto K: Molecular identification of guanine-nucleotide-binding regulatory proteins which couple to endothelin receptors. Eur J Biochem 1995;228:102-108.

-33 Doi T, Sugimoto H, Arimoto I, Hiroaki Y, Fujiyoshi Y: Interactions of endothelin receptor subtypes A and B with Gi, Go, and $\mathrm{Gq}$ in reconstituted phospholipid vesicles. Biochemistry 1999;38:3090-3099.

34 Aramori I, Nakanishi S: Coupling of two endothelin receptor subtypes to differing signal transduction in transfected Chinese hamster ovary cells. J Biol Chem 1992;267:12468-12474.

-35 Jouneaux C, Mallat A, Serradeil-Le Gal C, Goldsmith P, Hanoune J, Lotersztajn $\mathrm{S}$ : Coupling of endothelin $\mathrm{B}$ receptors to the calcium pump and phospholipase $\mathrm{C}$ via Gs and Gq in rat liver. J Biol Chem 1994;269:1845-1851.

36 Kitamura K, Shiraishi N, Singer WD, Handlogten ME, Tomita K, Miller RT: Endothelin-B receptors activate Ga13. Am J Physiol 1999;276:C930-C937.

-37 Knotek M, Jaksić O, Selmani R, Skorić B, Banfić H: Different endothelin receptor subtypes are involved in phospholipid signalling in the proximal tubule of rat kidney. Pflugers Arch 1996;432:165-173. 
38 Oakley RH, Laporte SA, Holt JA, Caron MG, Barak LS: Differential affinities of visual arrestin, beta arrestin1, and beta arrestin2 for $\mathrm{G}$ protein-coupled receptors delineate two major classes of receptors. J Biol Chem 2000;275:17201-10.

39 Hamdan FF, Rochdi MD, Breton B, Fessart D, Michaud DE, Charest PG, Laporte SA, Bouvier M: Unraveling G protein-coupled receptor endocytosis pathways using realtime monitoring of agonist-promoted interaction between $\beta$-arrestins and AP-2. J Biol Chem 2007;282:29089-29100.

40 Harris PJ, Zhuo J, Mendelsohn FA, Skinner SL: Haemodynamic and renal tubular effects of low doses of endothelin in anaesthetized rats. J Physiol 1991;433:25-39.

41 Perico N, Cornejo RP, Benigni A, Malanchini B, Ladny JR, Remuzzi G: Endothelin induces diuresis and natriuresis in the rat by acting on proximal tubular cells through a mechanism mediated by lipoxygenase products. J Am Soc Nephrol 1991;2:57-69.

42 Garvin JL, Herrera M, Ortiz PA: Regulation of renal $\mathrm{NaCl}$ transport by nitric oxide, endothelin, and ATP: clinical implications. Annu Rev Physiol 2011;73:359-376.

43 Uzuner K, Banks RO: Endothelin-induced natriuresis and diuresis are pressuredependent events in the rat. Am J Physiol 1993;265:R90-R96.

44 Freed MI, Thompson KA, Wilson DE, Etheredge R, Jorkasky DK: Endothelin receptor antagonism does not alter renal hemodynamic responses or urinary sodium excretion in healthy humans (abstract). J Am Soc Nephrol 1996;7:1580.

-45 Brooks DP, DePalma PD, Pullen M, Gellai M, Nambi P: Identification and function of putative ETB receptor subtypes in the dog kidney. J Cardiovasc Pharmacol 1995;26:S322-S325.

46 Clavell AL, Stingo AJ, Margulies KB, Brandt RR, Burnett JC Jr: Role of endothelin receptor subtypes in the in vivo regulation of renal function. Am J Physiol 1995;268:F455-F460.

47 Kamphuis C, Yates NA, McDougall JG: Differential blockade of the renal vasoconstrictor and diuretic responses to endothelin-1 by endothelin antagonist. Clin Exp Pharmacol Physiol 1994;21:329-333.
48 Bagnall AJ, Kelland NF, Gulliver-Sloan F, Davenport AP, Gray GA, Yanagisawa M, Webb DJ, Kotelevtsev YV: Deletion of endothelial cell endothelin B receptors does not affect blood pressure or sensitivity to salt. Hypertension 2006;48:286-293.

49 D’Orléans-Juste P, Labonté J, Bkaily G, Choufani S, Plante M, Honoré JC: Function of the endothelin(B) receptor in cardiovascular physiology and pathophysiology. Pharmacol Ther 2002;95:221-238.

50 Garcia NH, Garvin JL: Endothelin's biphasic effect on fluid absorption in the proximal straight tubule and its inhibitory cascade. J Clin Invest 1994;93:2572-2577.

51 Masereeuw R, Terlouw SA, van Aubel RA, Russel FG, Miller DS: Endothelin B receptormediated regulation of ATP-driven drug secretion in renal proximal tubule. $\mathrm{Mol}$ Pharmacol 2000;57:59-67.

52 Garvin J, Sanders K: Endothelin inhibits fluid and bicarbonate transport in part by reducing $\mathrm{Na}^{+} / \mathrm{K}^{+}$ATPase activity in the rat proximal straight tubule. J Am Soc Nephrol 1991;2:976-982.

53 Harris PJ, Thomas D: Effects of endothelin- 1 (ET) on proximal tubule fluid reabsorption (abstract). J Am Soc Nephrol 1990;1:416.

54 Phelps R, Guntupalli J: Effects of endothelin on Na-P1 cotransport in rat renal brush border membranes (BBM) (abstract). J Am Soc Nephrol 1990;1:580.

55 Liu Y, Yang J, Ren H, He D, Pascua A, Armando MI, Yang C, Zhou L, Felder RA, Jose PA, Zeng C: Inhibitory effect of $\mathrm{ET}_{\mathrm{B}}$ receptor on $\mathrm{Na}^{+}-\mathrm{K}^{+}$ATPase activity by extracellular $\mathrm{Ca}^{2+}$ entry and $\mathrm{Ca}^{2+}$ release from the endoplasmic reticulum in renal proximal tubule cells. Hypertens Res 2009;32:846-852.

56 Zeidel ML, Brady HR, Kone BC, Gullans SR, Brenner BM: Endothelin, a peptide inhibitor of $\mathrm{Na}-\mathrm{K}$-ATPase in intact renal tubular epithelial cells. Am J Physiol 1989;257:C1101-C1107.

57 Guntupalli J, DuBose TD Jr: Effects of endothelin on rat renal proximal tubule $\mathrm{Na}^{+}$Pi cotransport and $\mathrm{Na}^{+} / \mathrm{H}^{+}$exchange. Am J Physiol 1994;266:F658-F666. 
58 Peng Y, Moe OW, Chu T, Preisig PA, Yanagisawa $\mathrm{M}$, Alpern RJ: $\mathrm{ET}_{\mathrm{B}}$ receptor activation leads to activation and phosphorylation of NHE3. Am J Physiol 1999;276:C938-C945.

59 Chu TS, Tsuganezawa H, Peng Y, Cano A, Yanagisawa M, Alpern RJ: Role of tyrosine kinase pathways in $\mathrm{ET}_{\mathrm{B}}$ receptor activation of NHE3. Am J Physiol 1996;271:C763-C771.

60 Chu TS, Wu KD, Wu MS, Hsieh BS: Endothelin-1 chronically inhibits $\mathrm{Na} / \mathrm{H}$ exchanger-3 in $\mathrm{ET}_{\mathrm{B}}$-overexpressing $\mathrm{OKP}$ cells. Biochem Biophys Res Commun 2000;271:807-811.

61 Gregan B, Schaefer M, Rosenthal W, Oksche A: Fluorescence resonance energy transfer analysis reveals the existence of endothelin$\mathrm{A}$ and endothelin-B receptor homodimers. J Cardiovasc Pharmacol 2004;44(Suppl 1):S30-S33.

62 Gregan B, Jürgensen J, Papsdorf G, Furkert J, Schaefer M, Beyermann M, Rosenthal W, Oksche A: Ligand-dependent differences in the internalization of endothelin A and endothelin B receptor heterodimers. J Biol Chem 2004;279:27679-27687.

63 Davenport AP, Kuc RE: Down-regulation of $\mathrm{ET}_{\mathrm{A}}$ receptors in $\mathrm{ET}_{\mathrm{B}}$ receptor-deficient mice. J Cardiovasc Pharmacol 2004;44(Suppl 1):S276-S278.

64 Evans NJ, Walker JW: Sustained $\mathrm{Ca}^{2+}$ signaling and delayed internalization associated with endothelin receptor heterodimers linked through a PDZ finger. Can J Physiol Pharmacol 2008;86:526-535.

65 Boesen EI, Pollock DM: Cooperative role of $\mathrm{ET}_{\mathrm{A}}$ and $\mathrm{ET}_{\mathrm{B}}$ receptors in mediating the diuretic response to intramedullary hyperosmotic $\mathrm{NaCl}$ infusion. Am J Physiol Renal Physiol 2010;299:F1424-F1432.

66 Matsumura Y, Hashimoto N, Taira S, Kuro T, Kitano R, Ohkita M, Opgenorth TJ, Takaoka M: Different contributions of endothelin-A and endothelin-B receptors in the pathogenesis of deoxycorticosterone acetate-saltinduced hypertension in rats. Hypertension 1999;33:759-765.

67 Jose PA, Asico LD, Eisner GM, Pocchiari F, Semeraro C, Felder RA: Effects of costimulation of dopamine $\mathrm{D}_{1}$ - and $\mathrm{D}_{2}$-like receptors on renal function. Am J Physiol 1998;275:R986-R994.
68 Luippold G, Küster E, Joos TO, Mühlbauer $\mathrm{B}$ : Dopamine $\mathrm{D}_{3}$ receptor activation modulates renal function in anesthetized rats. Naunyn Schmiedebergs Arch Pharmacol 1998;358:690-693.

69 Zhang Y, Fu C, Ren H, He D, Wang X, Asico LD, Jose PA, Zeng C: Impaired stimulatory effect of $\mathrm{ET}_{\mathrm{B}}$ receptor on $\mathrm{D}_{3}$ receptor in immortalized renal proximal tubule cells of spontaneously hypertensive rats. Kidney Blood Press Res 2011;34:75-82

-70 Yu C, Yang Z, Ren H, Zhang Y, Han Y, He D, Lu Q, Wang X, Wang X, Yang C, Asico LD, Hopfer U, Eisner GM, Jose PA, Zeng C: $\mathrm{D}_{3}$ dopamine receptor regulation of ETB receptors in renal proximal tubule cells from WKY and SHRs. Am J Hypertens 2009;22:877-883.

71 Zeng C, Hopfer U, Eisner GM, Felder RA, Jose PA: Altered $\mathrm{AT}_{1}$ receptor regulation of ETB receptors in renal proximal tubule cells of spontaneously hypertensive rats. Hypertension 2005;46:926-931.

72 Zeng C, Wang Z, Asico LD, Hopfer U, Eisner GM, Felder RA, Jose PA: Aberrant ETB receptor regulation of AT receptors in immortalized renal proximal tubule cells of spontaneously hypertensive rats. Kidney Int 2005;68:623-631.

73 Shichiri M, Hirata Y, Ando K, Emori T, Ohta K, Kimoto S, Ogura M, Inoue A, Marumo F: Plasma endothelin levels in hypertension and chronic renal failure. Hypertension 1990;15:493-496.

74 Veglio F, Bertello P, Pinna G, Mulatero P, Rossi A, Gurioli L, Panarelli M, Chiandussi L: Plasma endothelin in essential hypertension and diabetes mellitus. J Hum Hypertens. 1993;7:321-325.

75 Schiffrin EL, Thibault G: Plasma endothelin in human essential hypertension. Am J Hypertens. 1991;4:303-308.

76 Davenport AP, Ashby MJ, Easton P, Ella S, Bedford J, Dickerson C: A sensitive radioimmunoassay measuring endothelinlike immunoreactivity in human plasma: comparison of levels in patients with essential hypertension and normotensive control subjects. Clin Sci (Lond) 1990;78:261-264 
77 Gariepy CE, Ohuchi T, Williams SC, Richardson JA, Yanagisawa M: Salt-sensitive hypertension in endothelin-B receptordeficient rats. J Clin Invest 2000;105:925933.

78 Williams JM, Pollock JS, Pollock DM: Arterial pressure response to the antioxidant tempol and $\mathrm{ET}_{\mathrm{B}}$ receptor blockade in rats on a high-salt diet. Hypertension 2004;44:770775 .
79 Pollock DM, Allcock GH, Krishnan A, Dayton BD, Pollock JS: Upregulation of endothelin B receptors in kidneys of DOCAsalt hypertensive rats. Am J Physiol Renal Physiol 2000;278:F279-F286.

80 Fryer RM, Rakestraw PA, Banfor PN, Cox BF, Opgenorth TJ, Reinhart GA: Blood pressure regulation by $\mathrm{ET}_{\mathrm{A}}$ and $\mathrm{ET}_{\mathrm{B}}$ receptors in conscious, telemetry-instrumented mice and role of $\mathrm{ET}_{\mathrm{A}}$ in hypertension produced by selective $\mathrm{ET}_{\mathrm{B}}$ blockade. Am J Physiol Heart Circ Physiol 2006;290:H2554-H2559. 